\title{
Ultrastructure of Archigetes sieboldi (Cestoda: Caryophyllidea): relationship between progenesis, development and evolution
}

\author{
Larisa G. Poddubnaya ${ }^{1}$, John S. Mackiewicz ${ }^{2}$ and †Boris I. Kuperman ${ }^{3^{*}}$ \\ ${ }^{1}$ Institute of Biology of Inland Waters, Russian Academy of Sciences, 152742, Borok, Yaroslavl Province, Russia; \\ ${ }^{2}$ Department of Biological Sciences, State University of New York, Albany, NY 12222, USA; \\ ${ }^{3}$ Biology Department, San Diego State University, 5500 Campanile Drive, San Diego, CA 92182-4614, USA
}

Key words: Archigetes sieboldi, ultrastructure, progenesis, evolution

\begin{abstract}
Ultrastructural characteristics of progenetic and monoxenic Archigetes sieboldi Leuckart, 1878 from the oligochaete Limnodrilus hoffmeisteri Claparède are described. Our observations demonstrate that progenetic Archigetes sieboldi shares characteristics of both larval (progenetic) and adult stages. The primary larval characteristics are: the presence of a cercomer; a surface filamentous coat covering the whole worm; the presence of the penetration glands and the absence of tegumental ones; wide sarcoplasmic processes connecting the circular and longitudinal external tegumental muscles; the absence of the dense homogenous zone of the basal lamina beneath the epithelial cytoplasm of all reproductive organs and ducts; non-functional gonopores; and an orthogonal plan of nervous system with three pairs of longitudinal nerve trunks. The principle adult characteristics are: oogenesis, spermiogenesis and vitellogenesis that produce fertilized eggs; the uterine glands; a well-developed longitudinal tegumental muscle layer between tegumental cytons; and the presence of different microtriches. As a result of this progenetic development there has been a secondary reduction in the life cycle of $A$. sieboldi. It is postulated that a similar process of progenesis may have played a major role in the early evolution of the Caryophyllidea by first appearing in a plerocercoid stage of an ancestral strobilate cestode from fish.
\end{abstract}

Questions of the origin and evolution of tapeworms continue to be a controversial subject in helminthology. A few groups of cestodes, such as the monozoic Caryophyllidea, have a highly disputed position (Hoberg et al. 1997, 1999, 2001, Mariaux 1998, Kodedová et al. 2000, Littlewood et al. 2001, Mariaux and Olson 2001, Olson et al. 2001). While oligochaetes typically serve as intermediate hosts of this group, several species, such as Archigetes sieboldi Leuckart, 1878 and A. iowensis Calentine, 1962, are monoxenic (Calentine 1964, Kennedy 1965). Because of the monozoic condition, the Caryophyllidea has been hypothesised as either being primarily monozoic and having a basal position among eucestodes, or as being secondarily derived from a segmented pseudophyllidean ancestor (see Mackiewicz 1972, 1981 for an extensive review and analysis of these two views).

There have been many proponents for either hypothesis. One hypothesis is that a monozoic strobila was ancestral for the eucestodes, as hypothesised by Cameron (1956), Llewellyn (1965), Freeman (1973), Stunkard (1975), Kulakovskaya and Demshin (1978), Dubinina (1980), Bazitov (1981), Ehlers (1985) and Malmberg (1986). In this case, oligochaetes are recognized as the original, primary hosts of the Caryophyllidea. An alternative hypothesis considers the lack of segmentation to be secondarily derived from a strobilate ancestor, namely the Pseudophyllidea (Nybelin 1922, 1962, Wiśniewski 1930, Fuhrmann 1931, Kirschenblat 1941, Wardle and McLeod 1952, Joyeux and Baer 1961, Mac- kiewicz 1972, 1981, 1982, Mamaev 1975, Poddubnaya et al. 1984, Poddubnaya 2002). This hypothesis recognizes fish as primary hosts. Recent analyses based on morphology and molecular data (Hoberg et al. 1997, 1999, 2001, Mariaux 1998, Littlewood et al. 2001, Mariaux and Olson 2001, Olson et al. 2001), though not resolving the origin of this group of tapeworms, present strong evidence of a basal position for the monozoic Caryophyllidea.

The question of whether or not the monozoic state is a primary or secondary one cannot be answered until the influence of progenesis in caryophyllidean development and evolution is resolved through a critical study of the progenetic status of Archigetes, the classical example of progenesis in the Caryophyllidea. Progenesis, or the precocious sexual maturation of an organism while it is morphologically and developmentally a juvenile, is often confused with neoteny, terms applied to a sexually mature adult stage that has retained juvenile characteristics.

The purpose of this paper is to confirm the progenetic status of $A$. sieboldi and to identify the larval and adult characteristics through study of the ultrastructure of tegument, glands, muscles, nervous and reproductive systems and the cercomer of $A$. sieboldi at different stages of development within oligochaetes.

*L.G.P. and J.S.M. express their deepest regret that Professor Boris I. Kuperman, distinguished scientist, colleague, and mentor and tutor of L.G.P., passed away during the preparation of this article, on 10 August 2002. 


\section{MATERIALS AND METHODS}

Different stages of Archigetes sieboldi were recovered from the coelom of the tubificid oligochaete, Limnodrilus hoffmeisteri Claparède, collected from the Latka, a small river that flows into the Rybinsk Reservoir. The collection site is very shallow, highly eutrophied, devoid of fish and with an extraordinarily high concentration of oligochaetes.

Archigetes sieboldi was subjected to two procedures: experimental infection in fish and culture. For infections, 20 mature and gravid worms from oligochaetes were force-fed by tube into the gut of 7 carp, Cyprinus carpio Linnaeus, potential definitive fish hosts. These carp were obtained from "Sunoga", site of experimental ponds of the Institute of Biology of Inland Waters, RAS and were free of worms. Experimentally infected carp were maintained in aquaria and examined for worms from 1 to 5 days later. For culture, 15 mature and gravid worms were placed in vials with a medium consisting of one part serum from blood of bream, Abramis brama Linnaeus, and 3 parts Hank's physiological solution, and incubated for $1,3,6,13$ or $24 \mathrm{~h}$ at $4^{\circ} \mathrm{C}$.

All specimens of $A$. sieboldi for electron microscopy were fixed in $2.5 \%$ glutaraldehyde in $0.1 \mathrm{M}$ sodium cacodylate buffer ( $\mathrm{pH}$ 7.2) for $1-2$ days at $4^{\circ} \mathrm{C}$, rinsed for 20 min 4 times in the same buffer, postfixed in $1 \%$ osmium tetroxide for $1 \mathrm{~h}$, dehydrated in a graded ethanol series and acetone, and embedded in Araldite. Semithin sections $(1 \mu \mathrm{m})$ were stained by methylene blue and examined with a light microscope (MFN-11). Ultrathin sections $(60-70 \mathrm{~nm})$ were double stained with uranyl acetate for $2 \mathrm{~h}$ at $20^{\circ} \mathrm{C}$, and Reynold's lead citrate for 20 minutes at $20^{\circ} \mathrm{C}$ for examination under a JEOL-100C transmission electron microscope (TEM) at $80 \mathrm{kV}$.

For histochemical study of glands, worms were fixed in Bouin's $\left(48 \mathrm{~h}\right.$ at $\left.4{ }^{\circ} \mathrm{C}\right)$ or Carnoy's $\left(10 \mathrm{~h}\right.$ at $\left.4^{\circ} \mathrm{C}\right)$ fixatives and tested for proteins, RNA, glycogen, and glycoproteins on 5-7 $\mu \mathrm{m}$ sections (Pearse 1960, Luppa 1977). Distribution of lipids was revealed by staining frozen sections with Sudan B after fixation in $10 \%$ neutral formalin.

The nervous system of $A$. sieboldi was demonstrated by the acetylthiocholine iodide technique of Gomori (1952) as modified by Kotikova (1967) that localises cholinesterase. Worms were fixed in $4 \%$ neutral formalin for $3 \mathrm{~h}$, followed by 2 rinses in distilled water. Specimens were then incubated in the acetylthiocholine iodide substrate for $20 \mathrm{~h}$ at $4^{\circ} \mathrm{C}, \mathrm{pH} 5.5$ and postfixed in $10 \%$ neutral formalin for $3 \mathrm{~h}$. Control specimens were incubated in the same medium supplemented with 3-5 drops of $1 \%$ proserin.

A morphometric analysis of the length, diameter and numbers of microvilli and microtriches per square unit area (1 $\mu \mathrm{m}^{2}$ ) was done using the method of Graeber and Storch (1979).
To avoid unnecessary confusion with the terminology of larval stages, we have retained the terms "procercoid" and "plerocercoid" as commonly used throughout the helminthological literature. The terminology of larval cestodes or metacestodes has recently been revised (Chervy 2002) to more closely follow the interpretations of Freeman (1973) when dealing with cercomer-bearing stage of caryophyllideans. Under the new revision, the cercomer-bearing stage of caryophyllideans is now a "caudate plerocercoid", or, in the case of Archigetes, a "progenetic caudate plerocercoid". Until this new terminology can be thoroughly assessed, we prefer the term "procercoid", particularly in the light of possible theories of the evolutionary origin of the Caryophyllidea.

The following terms are used to designate stages and levels of development for A. sieboldi: mature - any worm with fullyformed genital organs but without eggs; gravid - any worm with eggs; larva - stage between egg and adult that lives in the coelom of oligochaetes, and adult - stage that follows the larval stage and matures in the intestine of the vertebrate host.

\section{RESULTS}

\section{Tegument}

Differentiation of the tegument of $A$. sieboldi occurs in two stages: primary and secondary. The primary stage consists of a distal cytoplasmic layer with underlying primary tegumental cells, or cytons (Fig. 1). The distal layer is unusually thin $(0.63 \pm 0.03 \mu \mathrm{m})$, and possesses numerous dense secretory granules $(0.15 \pm$ $0.01 \times 0.10 \pm 0.01 \mu \mathrm{m})($ Fig. 2) that are derived from cytons that fuse with each other to form large, syncytial conglomerates (Fig. 1). Undifferentiated cells occur in the parenchyma below the primary cytons; short microvilli-like structures are on the surface of the primary tegument (Fig. 2). As development proceeds, the syncytial layer with primary tegumental cells degenerates, autophagosomes appear and secretory granules disappear.

Formation of the secondary tegument involves development of microtriches and a thick surface filamentous coat. It begins with the outward migration of slightly differentiated cells from underlying parenchyma and the presence of microvilli on the surface (Fig. 3). Microtriches are subsequently formed by accumulation of an electron-dense substance in the apical part of microvilli. At any time, therefore, one can find a mixture of microvilli and complete and incomplete microtriches (Fig. 4). As the procercoid matures, microtriches eventually replace all of the microvilli.

Figs. 1-6. Tegument of Archigetes sieboldi, two stages of the differentiation. Fig. 1. Syncytial conglomerate of primary tegumental cells. Fig. 2. The primary cover layer with secretory granules and microvilli-like structures. Fig. 3. Microvilli of secondary tegument. Fig. 4. Microtriches and microvilli of secondary tegument. Fig. 5. Cone-like microtriches. Fig. 6. Filamentous microtriches. Abbreviations: AP - apical parts of microtriches; BP - basal parts of microtriches; DB - electrondense bodies; DL - distal cytoplasmic layer; DM - electron-dense material; ML - microvilli-like structures; MT - microtriches; MV - microvilli; SC - syncytial conglomerate of primary cytons; SDC - slightly differentiated cells; SG - secretory granules. Scale bars: Fig. $1=5 \mu \mathrm{m}$; Fig. $2=0.5 \mu \mathrm{m}$; Fig. $3=4 \mu \mathrm{m}$; Figs. $4-6=0.2 \mu \mathrm{m}$. 


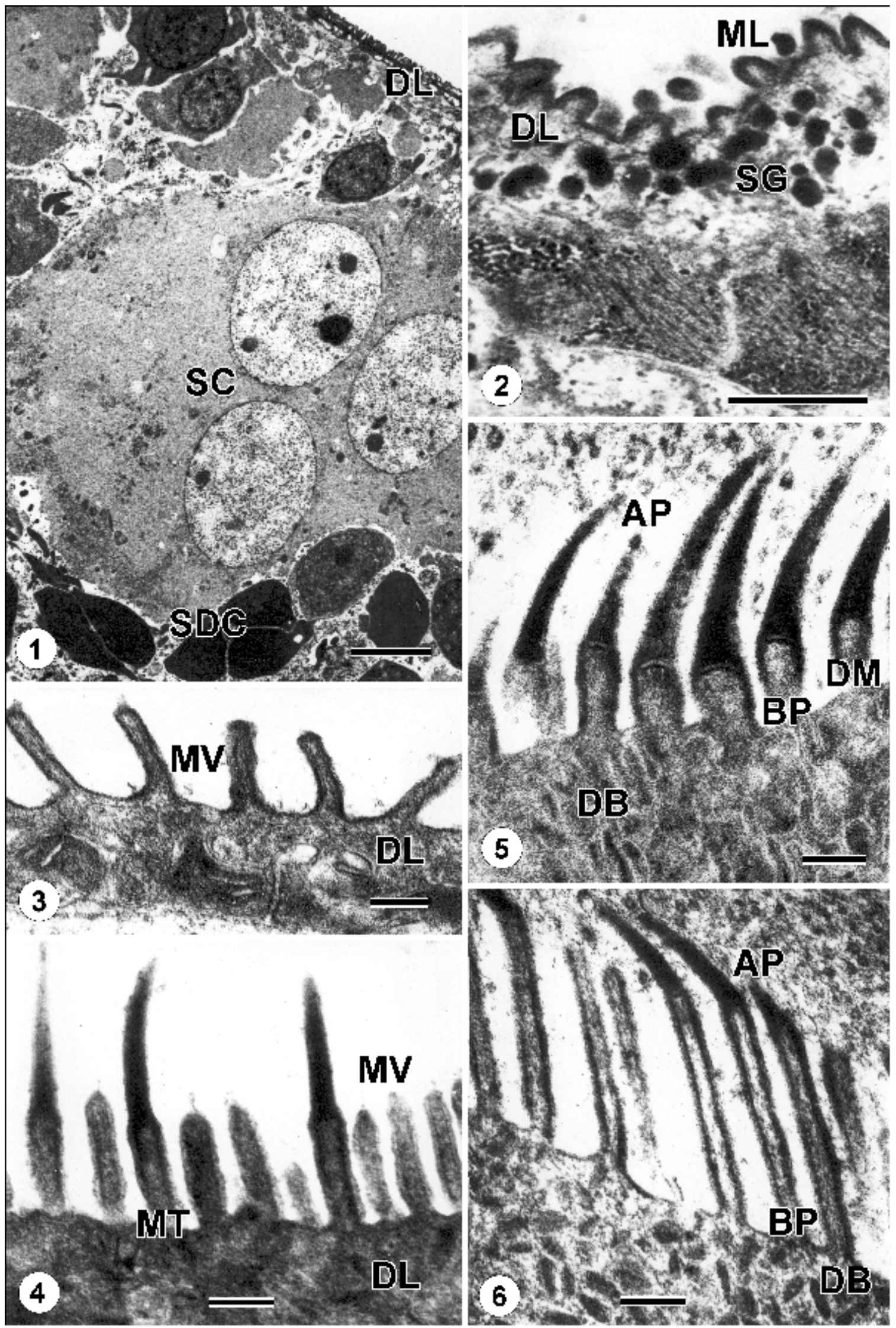



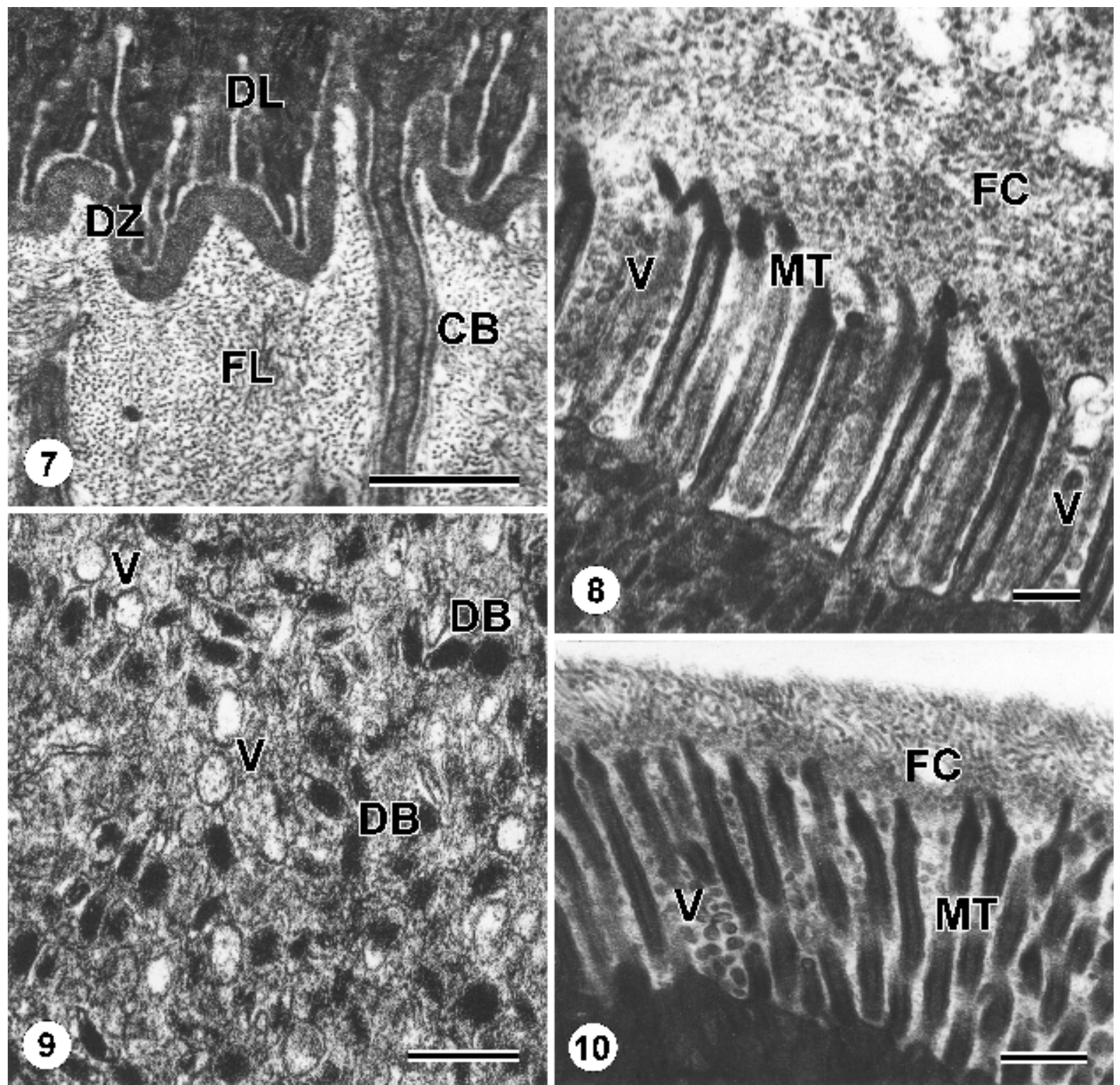

Figs. 7-10. Surface filamentous coat on tegument of gravid Archigetes sieboldi. Fig. 7. Two layers of basal lamina that are attached to distal cytoplasm of tegument. Figs. 8, 10. Thick filamentous coat on the outer aspect of tegument. Fig. 9. Various types of tegumentary bodies of distal cytoplasm. Abbreviations: CB - cytoplasmic bridge; DB - electron-dense bodies; DL distal cytoplasmic layer; DZ - dense zone of basal lamina; FC - filamentous coat; FL - fibrillar layer of basal lamina; MT microtriches; V - vesicles. Scale bars: Figs. 7, $10=0.5 \mu \mathrm{m}$; Figs. 8, $9=0.2 \mu \mathrm{m}$.

Figs. 11-16. Glands of gravid Archigetes sieboldi. Fig. 11. Cytoplasmic bridge between two penetration gland cells. Fig. 12. Formation of secretory granules in cytoplasm of the gland cell. Fig. 13. Secretory granules in ducts of penetration glands. Fig. 14. Exit of the secretion from the duct penetrating the tegumental distal cytoplasm. Fig. 15. Two types of frontal glands after incubation in bream's blood. Fig. 16. Processes of tegumental glands with secretory material that enters distal cytoplasm of scolex tegument. Abbreviations: AG - Golgi apparatus; CB - cytoplasmic bridge; DL - distal cytoplasmic layer; DPG - ducts of penetration glands; ER - endoplasmic reticulum; $\mathrm{M}$ - mitochondrion; $\mathrm{MR}$ - microtubule; $\mathrm{N}$ - nucleus; $\mathrm{PG}$ - penetration glands; PTG - processes of tegumental glands; SG - secretory granules; TG - tegumental glands. Scale bars: Figs. 11, 13, 15, $16=1 \mu \mathrm{m}$; Fig. $12=0.2 \mu \mathrm{m}$; Fig. $14=0.5 \mu \mathrm{m}$. 


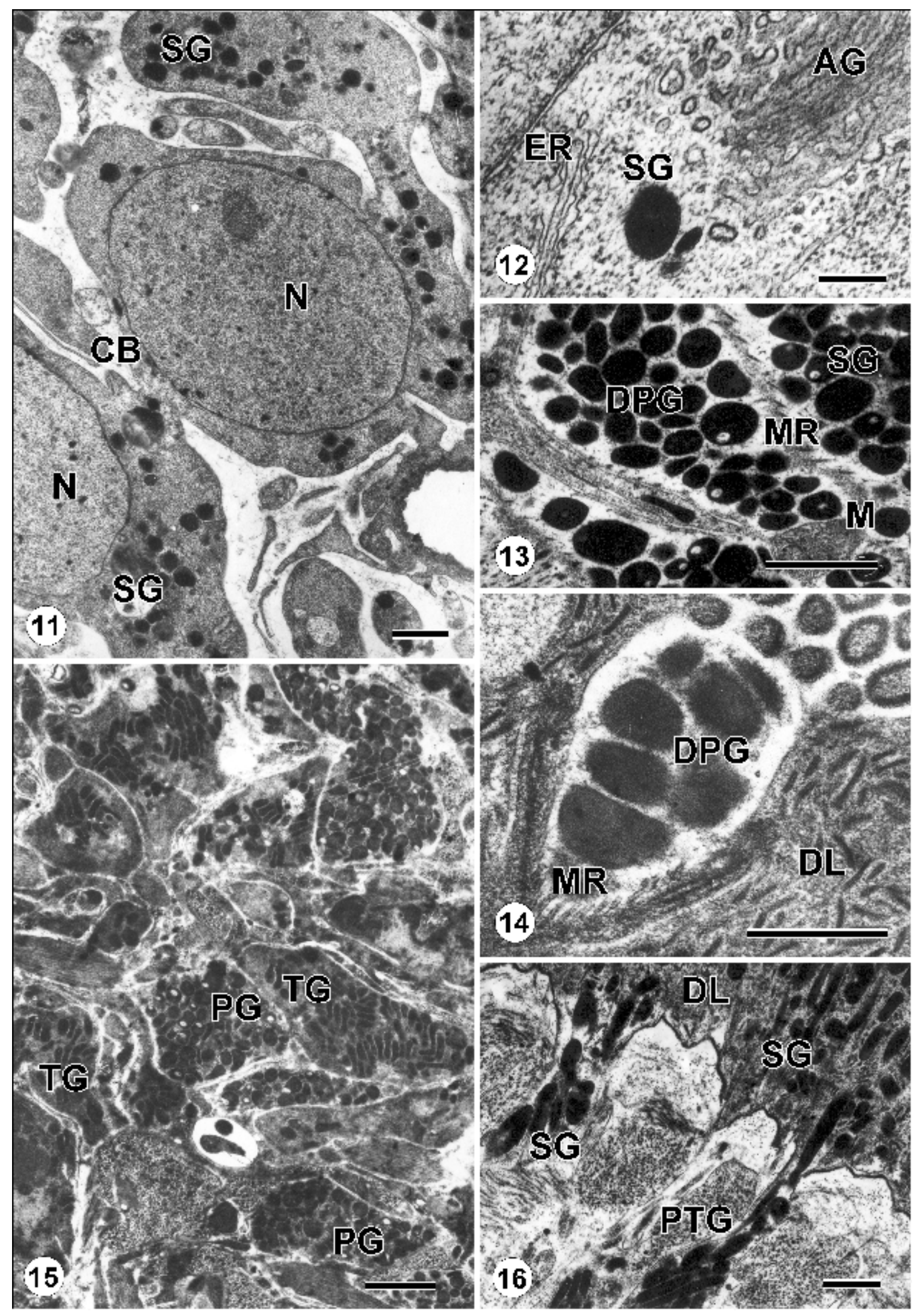


Two types of microtriches are observed. One is the cone-like microtrix of the attachment type that prevails on the scolex (Fig. 5). These microtriches have a base of $0.26 \pm 0.01 \mu \mathrm{m}$ in length and $0.19 \pm 0.01 \mu \mathrm{m}$ in width; their density is $19.0 \pm 1.6$ per square unit area $\left(1 \mu \mathrm{m}^{2}\right)$. The base, containing tegumental distal cytoplasm with many fine longitudinal microfilaments, is surrounded by thin electron-dense material that underlies the plasma membrane. An electron-dense spine, $0.65 \pm 0.07 \mu \mathrm{m}$ in length, is composed of closely packed, longitudinal tubular microfilaments. The second type is the filamentous microtriches (Fig. 6), localised in the middle and posterior part of the body. Filamentous microtriches are tubular with an elongated non-strengthened basal part $0.76 \pm 0.03 \mu \mathrm{m}$ in length, $0.11 \pm 0.1 \mu \mathrm{m}$ in width and with a short dense apical part $0.38 \pm 0.01 \mu \mathrm{m}$ in length. They are more densely arranged than the preceding type with $36.1 \pm 3.2$ per square micrometre.

The tegument of mature $A$. siebold $i$ in the oligochaete is an extensive syncytium attached to a basal lamina and sunken perikarya. The basal lamina consists of two layers, the outermost dense homogenous zone with closely spaced fibrils and the inner layer of a fibrillar extracellular lamina (Fig. 7).

Covering the whole worm is a thick filamentous coat on the outer aspect of the apical plasma membrane (Figs. 8, 10). The structure of this coat is uniform over the worm's surface and may reach $3 \mu \mathrm{m}$ in thickness. TEM examination of the distal cytoplasmic layer reveals the electron-dense bodies and numerous membrane-bounded vesicles, approximately 0.06-0.09 $\mu \mathrm{m}$ in diameter, randomly distributed in the syncytium (Fig. 9). This coat was not present on $A$. sieboldi cultured in immune blood of bream or on worms recovered from experimentally infected carp.

\section{Glands}

There is one type of unicellular gland in mature $A$. sieboldi from oligochaetes. The gland cells are localised in the central parenchyma of the scolex region and the middle part of the body. These cells are characterised by large nuclei and cytoplasm filled with rounded secretory granules of high electron density that are 0.13 to 0.54 $\mu \mathrm{m}$ in diameter (Fig. 11). The cytoplasm also has a well-developed Golgi complex, granular endoplasmic reticulum, and a number of mitochondria (Fig. 12). Cytoplasmic bridges may connect the individual gland cells with each other (Fig. 11). Processes from all the gland cells become ducts in which the secretory granules accumulate in the scolex (Fig. 13). These ducts, with walls strengthened by peripheral microtubules, pass through the tegument and discharge their secretory products. Circular hemidesmosomes and septate junctions connect the terminal part of each duct with the distal cytoplasm of the tegument (Fig. 14). Secretory granules are most numerous in the ducts just before gravid $A$. sieboldi rupture the body wall of oligochaete. Histochemically, these granules are proteinaceous.

Archigetes sieboldi from experimentally infected carp and culture have two types of frontal glands in the scolex (Fig. 15). One type, penetration glands and similar to that mentioned above, has microtubules in the duct walls. The second type, tegumental, lacks microtubules and is characterised by large, elongated electron-dense granules $(0.85 \times 0.25 \mu \mathrm{m})$ in their cytoplasm (Figs. 15, 16). These granules are discharged from the distal tegumental cytoplasm either as separate granules, in merocrine fashion, or as an apocrine secretion with granules enclosed in a small bit of tegumental cytoplasm. Histochemically, the secretions of these glands are positive for neutral glycoproteins.

\section{Muscles}

In the early procercoid stages, the individual muscle fibres are immediately beneath the distal tegumental layer (Fig. 17). Adjacent to these muscle fibres, the perikarya have a large nucleus surrounded by small amount of sarcoplasm with a large number of ribosomes. In a later procercoid stage, there is a network of muscle fibres that consists of an outer layer of circular and inner layer of longitudinal fibres that are joined to each other by wide sarcoplasmic processes (Fig. 18). These same muscles are subsequently separated by narrow sarcoplasmic processes in $A$. sieboldi that have been incubated for $13 \mathrm{~h}$ in culture media (Fig. 21).

Tegumental musculature of mature and gravid $A$. sieboldi from oligochaetes is characterised also by a well-developed longitudinal muscular layer that lays between tegumental cytons and consists of several longitudinal fibres (Fig. 19). The myocytons (Fig. 20), located at varying distances beneath these layers, contain an unusually large number of ribosomes, mitochondria, glycogen, and the profiles of the agranular endoplasmic reticulum.

\section{Nervous system}

The nervous system of mature and gravid $A$. sieboldi presents an orthogonal plan that does not involve the cercomer. Within the body, the nervous system consists of a cerebral ganglion at the anterior end with three pairs of longitudinal nerve trunks, all situated at the same level in the cortical parenchyma (Fig. 22). The lateral trunks are the largest ones. Less conspicuous, transverse commissures connect the main lateral longitudinal nerve cords with each other.

The nervous system of worms from culture or experimentally infected fish was not examined.

\section{Reproductive system}

The uterus consists of three distinct regions: two short distal and proximal, non-glandular portions that are separated by a long, middle glandular section. The epithelium of the non-glandular portions is a thin 


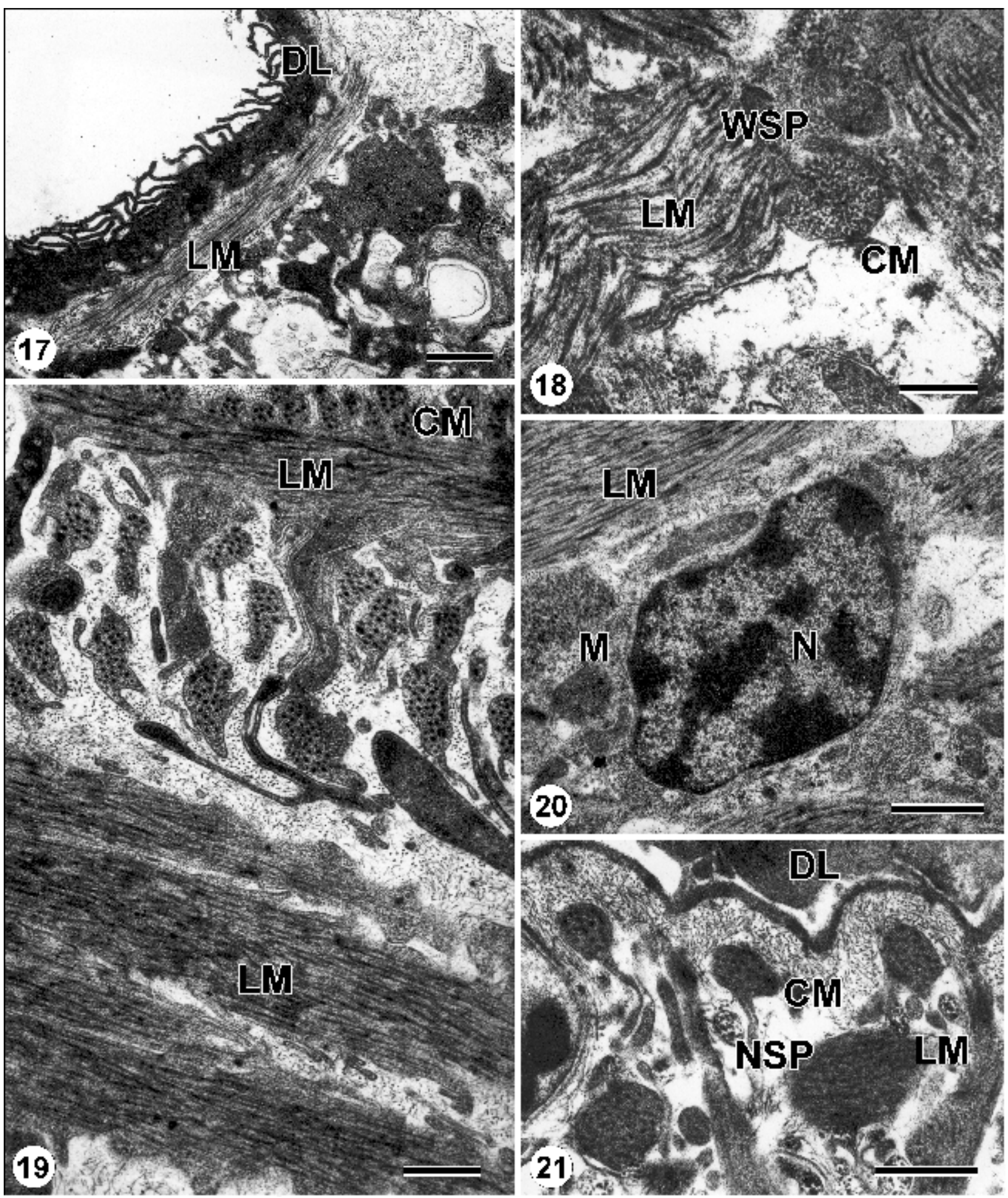

Figs. 17-21. The external tegumental group of muscles of Archigetes sieboldi. Fig. 17. Solitary muscles underlying the cover layer of early procercoid stage. Fig. 18. Wide sarcoplasmic processes between circular and longitudinal muscles of gravid worm from oligochaete body cavity. Fig. 19. The second well-developed longitudinal tegumental muscle layer of gravid worm. Fig. 20. Myocytons of the second longitudinal layer of muscle. Fig. 21. Narrow processes of sarcoplasm connect circular and longitudinal muscles from the 13-h culture. Abbreviations: CM - circular layer of muscles; DL - distal cytoplasmic layer; LM - longitudinal layer of muscles; $\mathrm{M}$ - mitochondrion; $\mathrm{N}$ - nucleus; NSP - narrow sarcoplasmic processes; WSP - wide sarcoplasmic process. Scale bars: Figs. $17,20=1 \mu \mathrm{m}$; Figs. $18,19,21=0.5 \mu \mathrm{m}$. 


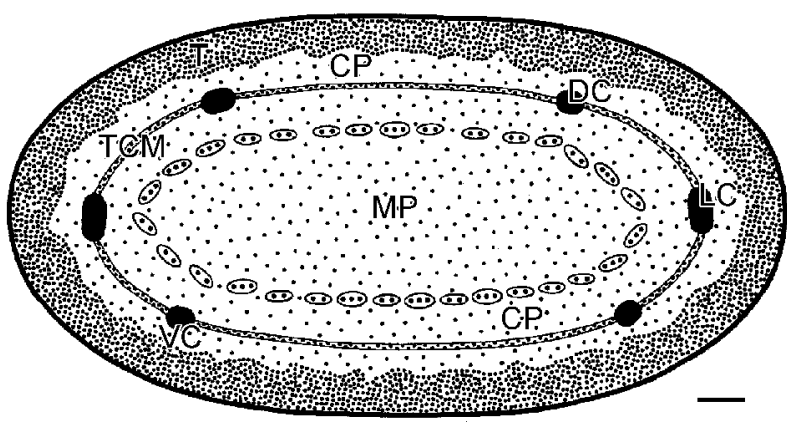

Fig. 22. Diagram of localisation of three pairs of longitudinal nerve cords in gravid Archigetes sieboldi. Abbreviations: CP cortical parenchyma; DC - dorsal nerve cords; LC - lateral nerve cords; MP - medullary parenchyma; $\mathrm{T}$ - tegument; TCM - transverse commissure; VC - ventral nerve cords. Scale bar $=130 \mu \mathrm{m}$.

syncytium with conspicuous microlamellae and prominent nuclei that bulge into the lumen (Fig. 23). A basement membrane and a thin extracellular matrix are present on the internal boundary of distal cytoplasm (Fig. 23). All reproductive ducts are attached to a basal lamina that is a thin fibrillar layer without a homogenous subepithelial dense zone (Figs. 23, 27, 29).

The longer, middle glandular portion of the uterus has the perikarya $20-25 \mu \mathrm{m}$ in diameter at varying distances beneath a syncytial layer (Figs. 24, 27). Cytoplasmic bridges connect the distal cytoplasmic layer with the uterine glands. Much of the perinuclear cytoplasm of the glands is filled with extensive granular endoplasmic reticulum having moderately dilated cisternae (Fig. 27). Between the cisternae are mitochondria, numerous free ribosomes and round electron-dense secretory granules 0.25 to $0.55 \mu \mathrm{m}$ in diameter (Figs. $24,27)$. Secretory granules pass through the cytoplasmic bridges into the epithelium and fill the syncytial layer of the uterine wall (Figs. 24, 27). These granules are then released into the uterine lumen (apocrine secretion), enclosed in small epithelial evaginations (Fig. 24). Some of these granules can be found around the shell of eggs (Fig. 25). Numerous long lamellae line the lumen of the distal part of the glandular section (Figs. 24, 27).

Within the ovary, all oocytes appear to be at the same stage of maturity and contain large dense nuclei, surrounded by dense cytoplasm. Vitellogenesis takes place and vitelline globules are clearly evident in the vitellocytes (Fig. 26); the nucleus also has the large glycogen inclusion, so characteristic of the Caryophyllidea.

Before joining the cirrus sac the vas deferens forms a muscular external seminal vesicle. The walls of both the external seminal vesicle and cirrus sac have a large number of myofibrils arranged in 25-30 closely arranged layers (Fig. 28). Between these layers of myofibrils and the peripheral layers of the sac wall are myocytons (Fig. 28). The large round cirrus sac (up to $160 \mu \mathrm{m}$ in diameter) has $9.30 \pm 0.93 \mu \mathrm{m}$ thick walls and contains the ejaculatory duct that has a thin syncytial cytoplasm and is covered with microlamellae (Fig. 29). The cirrus consists of a syncytial cytoplasmic layer, $1.25 \pm 0.15 \mu \mathrm{m}$ thick, lined internally by microtriches that are uniform in size (Fig. 30). The bases of the microtriches are $0.53 \pm 0.03 \mu \mathrm{m}$ long and $0.08 \pm 0.01$ $\mu \mathrm{m}$ in diameter and the shaft $0.80 \pm 0.05 \mu \mathrm{m}$ long. The aggregations of myocytons around the cirrus have long narrow processes of sarcoplasm-like lamellae (Fig. 31).

The spermatozoa are readily visible in the testis (Fig. 32), vas deferens, ejaculatory duct (Fig. 29), and vagina, all evidence of active spermiogenesis.

\section{Cercomer}

Progenetic A. sieboldi are characterised by a welldeveloped cercomer attached to the body by a narrow stem. It begins as a small protuberance that gradually increases proportionally in size to the length of the worm. Its tegument has a typical syncytial structure. The distal cytoplasm contains numerous free ribosomes and mitochondria (Fig. 33). Microvilli, with a length of $0.34 \pm 0.01 \mu \mathrm{m}$ and a diameter of $0.08 \pm 0.01 \mu \mathrm{m}$, cover the tegument of the whole cercomer (Fig. 34). Beneath the distal cytoplasm are electron-dense tegumental cells with large nuclei, free ribosomes, and mitochondria (Fig. 33). Glycogen is present in much of the parenchyma in these early stages of development (Fig. 35).

With elongation and growth of the worm, the cercomer tegument changes. The peripheral and perinuclear cytoplasm of underlying tegumental cytons fills with electron-dense round-oval granules $(0.13 \pm 0.01 \mu \mathrm{m})$, extensive granular endoplasmic reticulum, very welldeveloped Golgi apparatus, free ribosomes, and mitochondria (Fig. 37). The distal cytoplasm has also numerous electron-dense granules (Fig. 36). Microtriches were never observed on the cercomer of gravid A. sieboldi. With maturation of the procercoid, glycogen is depleted from the cercomer.

Figs. 23-27. Uterus and vitelline cells of Archigetes sieboldi. Fig. 23. Non-glandular portion of uterine epithelium. Fig. 24. Glandular portion of uterus with glandular cytons. Fig. 25. Shell of egg with secretory granules around it. Fig. 26. Vitelline cell from vitellarium. Fig. 27. Cytoplasm of uterine gland with extensive granular endoplasmic reticulum. Abbreviations: CB cytoplasmic bridges; ER - endoplasmic reticulum; FL - fibrillar layer of basal lamina; FUW - fragments of uterine wall; LM longitudinal layer of muscles; MCL - microlamellae; N - nucleus; SE - shell of egg; SG - secretory granules; UG - uterine glands; UL - uterine lumen; UW - uterine wall; VG - vitelline globules. Scale bars: Figs. 23, $27=1 \mu \mathrm{m}$; Fig. $25=0.5 \mu \mathrm{m}$; Figs. $24,26=2 \mu \mathrm{m}$. 


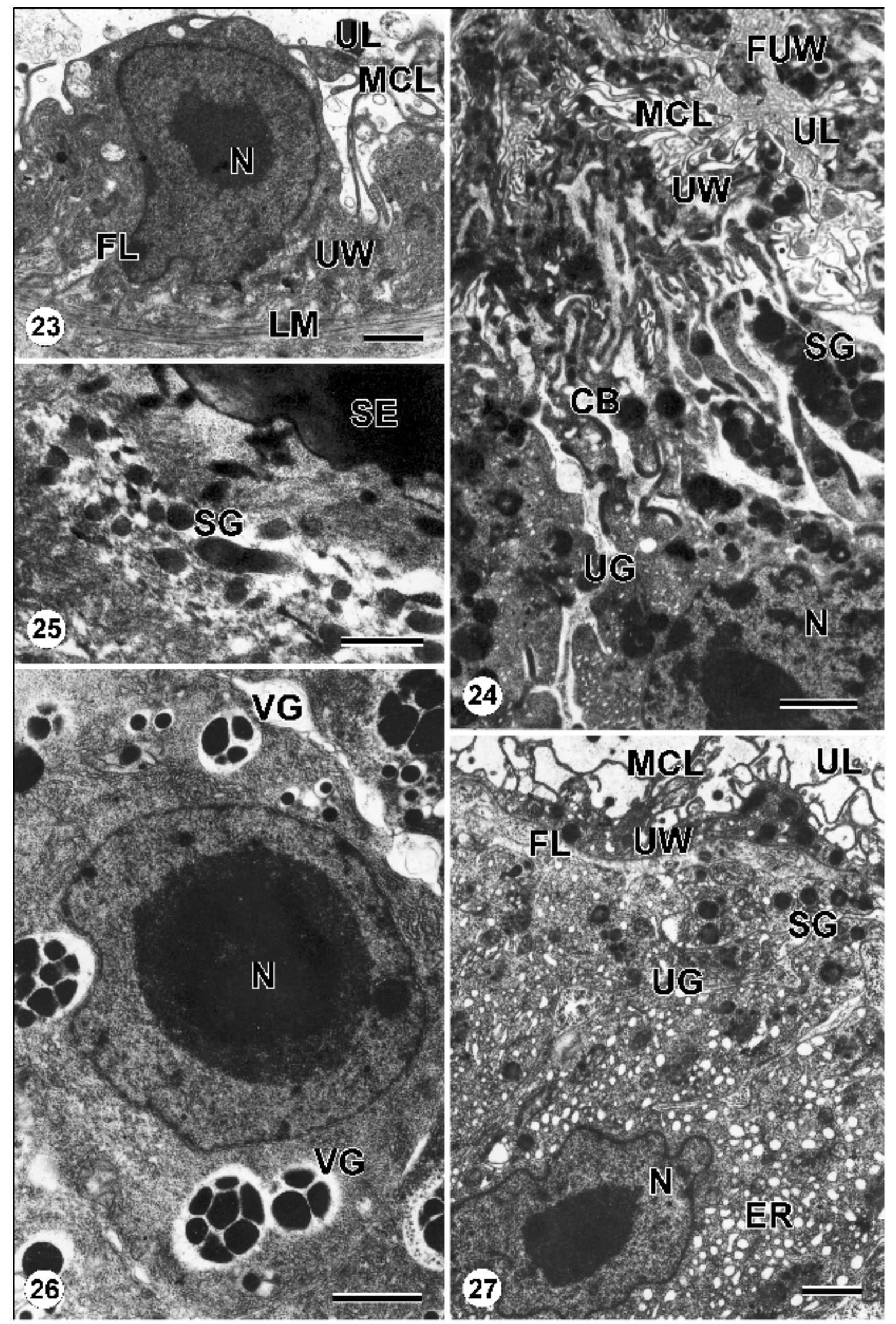




\section{DISCUSSION}

The species of Archigetes hold a special place among all cestodes because of their monoxenic life cycle: they are parasites of invertebrates that may reach sexual maturity in the coelom of aquatic oligochaetes. Species such as $A$. sieboldi and $A$. iowensis can have not only the usual two-host, oligochaete-fish cycle, characteristic of the Caryophyllidea, but also a monoxenic one in oligochaetes. If there are high densities of oligochaetes, populations of $A$. sieboldi can thrive without any vertebrate host, as is the case in the present study. Given this invertebrate-only cycle, as well as the monozoic body plan, it is possible to regard Archigetes as primitive cestodes whose ancestors were originally parasites of invertebrates. One might thus consider Archigetes a relict cestode. On the other hand, a second possibility is that Archigetes is simply a progenetic procercoid. In this case, the progenetic, cercomer-bearing stage (procercoid) may have evolved, and is secondarily derived, from a cycle that once had a plerocercoid and a strobilate, intestinal stage in fish.

Morphological and developmental data from our study strongly reinforces the progenetic status of $A$. sieboldi. From Table 1, one can see that $A$. siebold $i$ shares characteristics of both larval (procercoid) and adult stages. The coelom habitat and presence of a cercomer are self-evident characteristics of a larval (procercoid) stage and need no further elaboration. On the other hand, additional information on each of the other characteristics in this comparative table is given below.

The ultrastructure of the tegument of $A$. siebold $i$ undergoes pronounced morphological changes during procercoid development. The primary tegument of caryophyllidean procercoids is specialised in secretory activity, perhaps associated with the immune attack of oligochaete coelomocytes, as described by Calentine et al. (1970). In later stages, with the second tegument, a thick filamentous coating forms on the worm's surface, similar to the dense glycocalyx layer observed on the tegument of other caryophyllidean procercoids (Poddubnaya 1995). This glycocalyx also appears to be similar to that covering the cyst of progenetic Diplocotyle olrikii from the body cavity of invertebrate host (Davydov et al. 1997). As in the spathebothriid cestode $D$. olrikii, the glycocalyx of $A$. sieboldi is also lost after the cestode is in the vertebrate intestine, as verified by experimental infections of procercoids in carp. Furthermore, A. sieboldi incubated for up to $24 \mathrm{~h}$ in immune fish serum generally showed the absence of such glycocalyx. This loss suggests a protective function for the glycocalyx while the larval cestode is in the coelom of the intermediate host. This thick filamentous coat has also been described for larval stages of many other tapeworms (Davydov and Mikryakov 1988, Davydov et al. 1997). There is evidence that the glycocalyx of tapeworms and trematodes is a dynamic structure. For example, in Hymenolepis diminuta the turnover time for the ${ }^{3} \mathrm{H}$-galactose labeled constituent appears to be about six hours (Oaks and Lumsden 1971). In Fasciola hepatica, the turnover continues throughout the life of the fluke (Hanna 1980a, b). Apparently the absence of filamentous coat on the tegumental surface of adult Caryophyllidea from the intestine of fish (Bequin 1966, Poddubnaya et al. 1986) is compensated for by well-developed tegumental glands that produce a complex glycoprotein that may also have a protective function against the vertebrate immune response (Davydov and Poddubnaya 1988). The presence of a filamentous coat or glycocalyx on progenetic $A$. sieboldi and its absence from subsequent stages further confirms the larval status of the gravid Archigetes stage from oligochaetes.

As in other cestodes, the tegument of Archigetes contains various types of bodies. Examination of the distal cytoplasmic layer reveals electron-dense bodies and numerous membrane-bounded vesicles, randomly distributed in the syncytium. Both the bodies and vesicles were observed at the surface of Archigetes in various stages of exocrine discharge. Early studies have implicated electron-dense bodies as sources of raw materials for microthrix synthesis in the Caryophyllidea (Richards and Arme 1981, 1982, Poddubnaya 1996). Electron-lucid vesicles, on the other hand, have been described as pinosomes and secretory vesicles (Oaks and Lumsden 1971, Lumsden 1975, Threadgold and Hopkins 1981, Yamane et al. 1982, Oaks and Holy 1994). Autoradiographic studies indicate that tegumental vesicles of parasitic worms give rise to the glycocalyx (Oaks and Lumsden 1971, Hanna 1980b). Histochemical, cytochemical and biochemical studies of different helminths (Baron 1968, Smyth 1969, Oaks and Lumsden 1971, Lumsden 1975, Threadgold 1976) have shown that the secretory vesicles contain glycoproteins. The glycocalyx lies at the interface with the host and may protect the worm against the host's enzymatic activity (Lumsden at al. 1974, Yamane et al. 1982, Pappas and Uglem 1990, Oaks and Holy 1994).

Figs. 28-32. The cirrus sac and testis of Archigetes sieboldi. Fig. 28. The wall of cirrus sac. Fig. 29. Ejaculatory duct with sperm. Fig. 30. Epithelium of cirrus covered with microtriches. Fig. 31. Myocyton of cirrus sac with sarcoplasm-like lamellae. Fig. 32. Testis with spermatozoa attached to basal membrane. Abbreviations: AP - apical parts of microtriches; BM - basal membrane; $\mathrm{BP}$ - basal parts of microtriches; CSL - lumen of the cirrus sac; CSW - wall of the cirrus sac; DL - distal cytoplasmic layer; FL - fibrillar layer of basal lamina; IC - part of invaginated cirrus; MC - myocytons; MCL - microlamellae; MF - myofibrils; MT microtriches; SL - sarcoplasm-like lamellae; SP - sperm. Scale bars: Fig. $28=5 \mu \mathrm{m}$; Fig. $29=1 \mu \mathrm{m}$; Figs. $30,32=0.5 \mu \mathrm{m}$; Fig. $31=2 \mu \mathrm{m}$. 


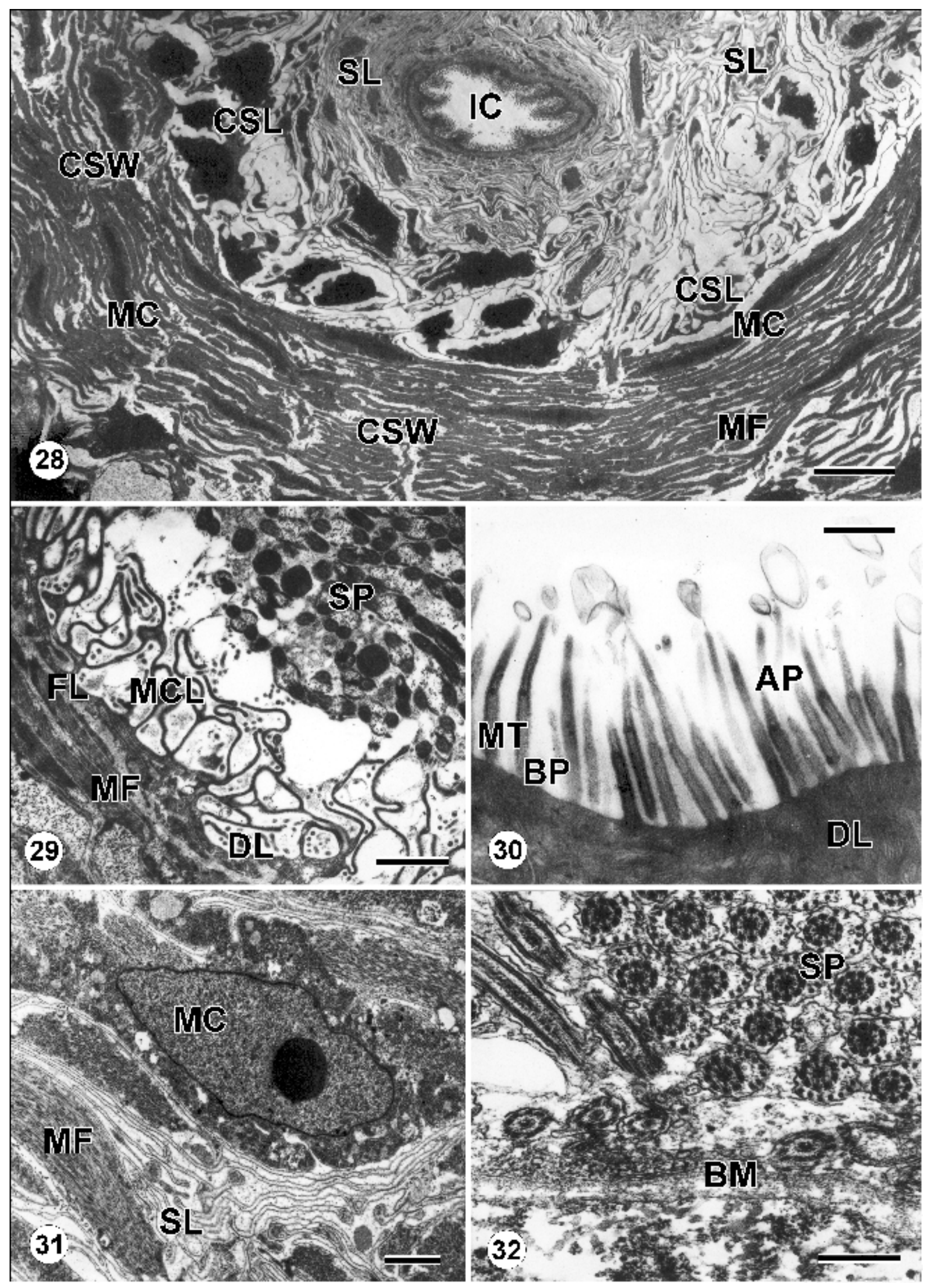


Microvilli formation and their replacement with microtriches appear to be the general processes in all cestodes (Kuperman 1988). Specialised types of microtriches are a result of adaptation to various conditions in the intestine of vertebrate hosts. While microvilli tend to predominate in larval stages, they are eventually replaced by microtriches as the cestode matures in the vertebrate intestine. However, the sequence of development is quite different in $A$. siebold $i$ - microtriches finish their development while the cestode is still in the coelom of the invertebrate host. The fully developed microtriches of $A$. sieboldi show the typical ultrastructural features characteristic of adult tapeworms. There is, therefore, precocious maturation of the microtriches. Under these circumstances, microthrix function is unclear because the coelom lacks the high nutritional resources and motility of the vertebrate intestine.

There are many reports of gland cells in larval and adult tapeworms (see review of Whittington and Cribb 2001). Specialised unicellular glands appear to be frequent in larval cestodes. The general consensus is that the frontal glands of larvae are to facilitate penetration of the larva into the intermediate host (Lethbridge and Gijsberrs 1974, Goggins 1980, Kuperman and Davydov 1981, Kuperman 1988, Moczoń 1996). The occurrence of such glands only in procercoids of $A$. sieboldi may be connected with their living in the coelom of the oligochaete intermediate host. In this case, the penetration glands may help gravid $A$. sieboldi leave the body cavity of an oligochaete in order to continue its life cycle.

The tegumental glands of the scolex of adult Caryophyllidea are modified tegumental cells of the anterior part of the body (Hayunga 1979, Timoshechkina 1984, Davydov and Poddubnaya 1988) that may facilitate attachment to the intestinal mucosa (Mackiewicz 1972, Hayunga 1979). The fact that tegumental glands appeared in the scolex of $A$. sieboldi after incubation of worms in native serum of bream's blood or experimental infection in carp, suggests that the secretion of neutral glycoproteins from these glands may assist in protecting the worms from the host's immune response (Davydov and Poddubnaya 1988).

The presence of a longitudinal group of muscles between tegumental cytons is like that described in the adult caryophyllids, Caryophyllaeus laticeps and Khawia sinensis (Poddubnaya et al. 1986) and Lytocestus parvulus (Furtado 1963), and in Ligula intestinalis (Pseudophyllidea) by Dubinina (1966). These welldeveloped tegumental muscles may be an adaptation for resisting peristalsis, particularly in worms having a poorly developed holdfast. It seems most likely that the presence of these muscles in A. sieboldi is not an adaptation for life in the non-motile environment of the coelom, but rather an acceleration or precocious development of an adult characteristic, as in the reproductive system. Progenesis then can involve not only the reproductive system but also muscles as well.

There does appear to be a discreet difference, however, between the connections of some of the same muscle groups in progenetic worms and those in adult stages. In progenetic $A$. sieboldi, there are wide sarcoplasmic processes between circular and longitudinal layers of the external tegumental muscles. This appears to be a procercoid trait of the Caryophyllidea because it has also been found in procercoids of $C$. laticeps, $K$. sinensis and $K$. armeniaca (Poddubnaya 1995). In adult caryophyllideans from the intestine of fish, on the other hand, narrow processes of sarcoplasm connect these muscles to one another to form a syncytial structure (Poddubnaya et al. 1986). A. sieboldi from the 13-h culture have the narrow muscle processes like those of adult caryophyllid worms.

Our observations on the nervous system corroborate those of Wiśniewski (1930) that there are three pairs of longitudinal nerve cords in $A$. sieboldi. A similar number was observed earlier in $A$. appendiculatus ( $=A$. sieboldi) by Mrázek (1898). In adult caryophyllideans, on the other hand, the number of longitudinal nerve cord pairs is reported to be four in C. laticeps (Rahemo and Al-Kalak 1995), three in Lytocestus indicus (Lyngdoh and Tandon 1992), and five in C. laticeps (Will 1893, Kotikova 1976) and Djombangia penetrans (Lyngdoh and Tandon 1994).

The orthogonal pattern of three pairs of longitudinal nerve cords, also found in procercoids of the Pseudophyllidea, is regarded as the initial pattern of the nervous system for cestodes (Kotikova 1976, Kotikova and Kuperman 1977). According to Kotikova and Kuperman (1978), the scolex of all adult pseudophyllidean cestodes is innervated by five pairs of longitudinal nerve cords, the same number found in some caryophyllideans. In adult pseudophyllidean tapeworms such as Diphyllobothrium, the number of fine longitudinal nerve cords may gradually increase to 60 pairs in the widest parts of the strobila (Kotikova and Kuperman 1978).

The ultrastructure and secretions of the uterine glands of progenetic $A$. sieboldi are similar to that of adult caryophyllids (Table 1). In adult tapeworms, the uterus can play an active role in the protection of eggs. For example, there are the uterine modifications involving a paruterine organ and parenchymatic capsule formation in the cyclophyllidean family Nematotaeniidae or uterine capsule formation without such an organ in the Dipylidiidae (Conn et al. 1984, Conn 1988, Swiderski and Tkach 1997). In the Caryophyllidea, it appears that the conspicuous uterine glands may provide eggs with a protective coating, similar to that described for spathebothriids by Davydov et al. (1997). In both of these groups, the uterine glands are a modification of a sunken syncytial epithelium of the middle section of the uterus that produces a thick mucous-like envelope 


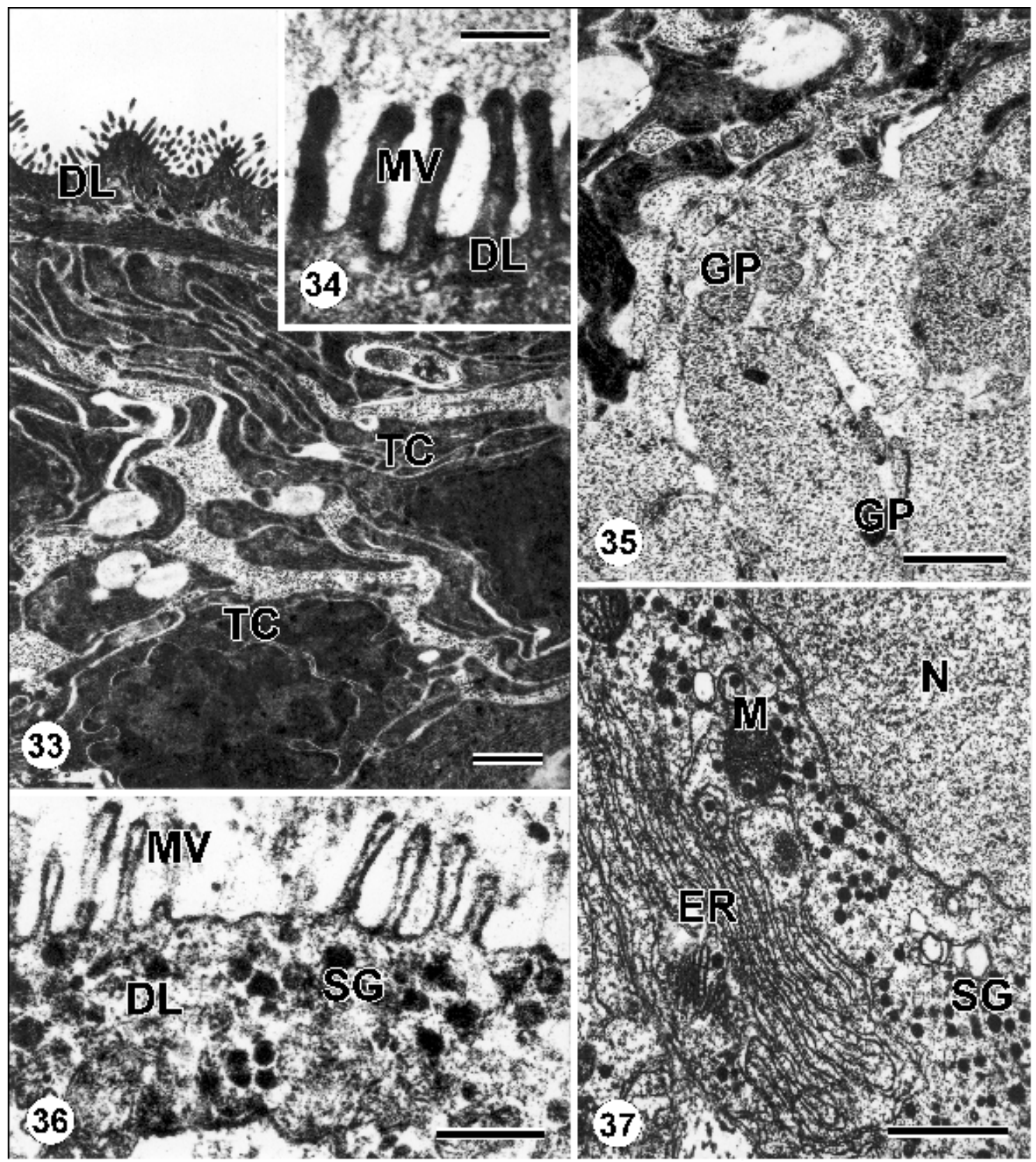

Figs. 33-37. The cercomer of Archigetes sieboldi. Fig. 33. Tegument of cercomer of immature worm. Fig. 34. Microvilli of cercomer syncytial cytoplasm. Fig. 35. Processes with glycogen of cercomer parenchyma. Fig. 36. Distal cytoplasm of gravid worm with electron-dense granules. Fig. 37. Tegumental secretory cyton of gravid worm. Abbreviations: DL - distal cytoplasmic layer; ER - endoplasmic reticulum; GP - processes with glycogen; M - mitochondria; MV - microvilli; N - nucleus; SG secretory granules; TC - tegumental cells. Scale bars: Figs. 33, 35-37 $=1 \mu \mathrm{m}$; Fig. $34=0.2 \mu \mathrm{m}$.

around eggs. Our histochemical tests verify earlier ones (Davydov and Poddubnaya 1988) that this secretion is a lipoprotein. According to these authors, the mucous-like envelope may protect eggs during their transport within the fish intestine. The present study, on the other hand, describes the same type of uterine glands in $A$. siebold $i$ from the body cavity of an invertebrate. This basic ultrastructural similarity between uterine glands of procercoids of $A$. sieboldi to those of adult caryophyllidean and spathebothriidean worms (Davydov and Poddubnaya 1988, Davydov et al. 1997) is additional evidence of a secondary reduction of the life cycle of Archigetes.

We found that the oocytes and the intrauterine eggs of progenetic $A$. sieboldi showed little variation in their state of development. Normally, oogenesis and egg 
Table 1. Comparison of characteristics of progenetic Archigetes sieboldi with oligochaete and vertebrate stages of other Caryophyllidea.

\begin{tabular}{|c|c|c|c|}
\hline Characteristic & $\begin{array}{c}\text { Other Caryophyllidea: } \\
\text { oligochaete stage procercoid }\end{array}$ & $\begin{array}{l}\text { Archigetes sieboldi: } \\
\text { progenetic procercoid }^{2}\end{array}$ & Vertebrate stage (adult)* \\
\hline Living site & coelom & coelom & intestine (fish) \\
\hline Cercomer & present & present & absent \\
\hline Tegument & $\begin{array}{l}\text { a) primary tegument present } \\
\text { b) secondary tegument with micro- } \\
\text { villi; two types of microtriches, } \\
\text { cone-like and filamentous, } \\
\text { formed on the base of microvilli } \\
\text { c) surface filamentous coat present }\end{array}$ & as in procercoid & $\begin{array}{l}\text { a) primary tegument absent } \\
\text { b) secondary tegument with cone-like and } \\
\text { filamentous microtriches, microvilli } \\
\text { absent } \\
\text { c) surface filamentous coat absent }\end{array}$ \\
\hline Glands & $\begin{array}{l}\text { a) penetration glands present, } \\
\text { many } \\
\text { b) tegumental glands absent }\end{array}$ & as in procercoid & $\begin{array}{l}\text { a) penetration glands present, few } \\
\text { b) tegumental glands present }\end{array}$ \\
\hline $\begin{array}{l}\text { Tegumental } \\
\text { muscles }\end{array}$ & $\begin{array}{l}\text { a) wide sarcoplasmic processes } \\
\text { between external circular and } \\
\text { longitudinal muscle groups } \\
\text { b) longitudinal muscle layer } \\
\text { between tegumental cytons absent }\end{array}$ & a) as in procercoid & $\begin{array}{l}\text { a) narrow sarcoplasmic processes between } \\
\text { external circular and longitudinal } \\
\text { muscle groups } \\
\text { b) longitudinal muscle layer between } \\
\text { tegumental cytons present }\end{array}$ \\
\hline $\begin{array}{l}\text { Nervous } \\
\text { system }\end{array}$ & 3 pairs of longitudinal nerve cords & as in procercoid & 5 pairs of longitudinal nerve cords \\
\hline $\begin{array}{l}\text { Reproductive } \\
\text { system }\end{array}$ & $\begin{array}{l}\text { a) uterine glands absent } \\
\text { b) organs and ducts attached to a } \\
\text { basal lamina with only a fibrillar } \\
\text { layer, dense zone absent } \\
\text { c) spermiogenesis absent } \\
\text { d) vitellogenesis absent }\end{array}$ & $\begin{array}{l}\text { c) as in adult } \\
\text { d) as in adult }\end{array}$ & $\begin{array}{l}\text { a) uterine glands present } \\
\text { b) organs and ducts attached to a basal } \\
\text { lamina with well-developed dense zone } \\
\text { and fibrillar layer } \\
\text { c) spermiogenesis present } \\
\text { d) vitellogenesis present }\end{array}$ \\
\hline Gonopore & closed by tegument & as in procercoid & open \\
\hline $\begin{array}{r}\text { Becomes } \\
\text { gravid }\end{array}$ & no & yes & yes \\
\hline
\end{tabular}

${ }^{1}$ caudate plerocercoid and ${ }^{2}$ progenetic caudate plerocercoid (terminology of Chervy 2002); *Khawia armeniaca, K. sinensis, Caryophyllaeus laticeps, Caryophyllaeides fennica

production in adult caryophyllideans occur over a period of time as eggs are gradually discharged into the lumen of the host's intestine. In A. sieboldi, on the other hand, (a) oogenesis may be rapid and (b) large numbers of eggs accumulate in the uterus and under the tegument because of a layer of tegument over the genital pore (Mrázek 1898, Wiśniewski 1930, Calentine and DeLong 1966). As the worm becomes gravid and increases in size, it ruptures the weakened body wall of the annelid and is liberated into the environment where it soon dies, disseminating all of the eggs at the same time.

Related to the reproductive system is the difference between the basal lamina of adult and progenetic stages. The reproductive organs and syncytial epithelium of all ducts of adult $C$. laticeps are attached to a well-developed basal lamina (Davydov et al. 1994) that exhibits a bilayered arrangement consisting of the subepithelial dense zone (homogenous) and a deeper fibrillar layer. The basal lamina of $A$. sieboldi, however, consists only of a single, thin fibrillar layer. This single layer structure presumably is a larval or procercoid trait. The functional significance of this difference is unclear, but may indicate that, like the muscle processes discussed above, the histological structure of some part of the ducts, i.e. basal lamina, still reflects the larval state of development.

In all other respects the structure and function of the reproductive system appears similar to that of adult caryophyllideans. Spermiogenesis and vitellogenesis both appear normal by producing viable sperm and the vitelline (shell) and glycogen constituents of eggs. Vitellogenesis produces numerous vitelline globules and a conspicuous glycogen inclusion in the nucleus, as described in Glaridacris catostomi by Swiderski and Mackiewicz (1976). Specific details of spermiogenesis and spermatogenesis are currently under study by the senior author. The cirrus sac and associated structures of Archigetes are fully developed and similar to those of adult caryophyllideans. The lamellar structure of the myocytons of the cirrus sac no doubt facilitates flexibility of the copulatory organ, allowing for the possibility of cross-insemination in the adult, vertebrate-dwelling stage. However, in the progenetic stage there can be only self-insemination because the tegument is not perforated over the genital pore. Sperm were readily observed in the testes, ejaculatory duct and vagina, indicating that the male reproductive system is fully functional in progenetic Archigetes. 
A cercomer is characteristic of the procercoid stage of caryophyllidean cestodes and is the strongest evidence that $A$. siebold $i$ in oligochaetes is still at the larval stage of development. As the cestode grows and undergoes morphogenesis, the cercomer assumes an absorptive-trophic function. It is not surprising, therefore, that microvilli assume the absorptive function rather than microtriches that are better adapted for conditions in the vertebrate intestine. A trophic function is indicated by the changes in glycogen distribution: glycogen is common in the developing cercomer, but with morphogenesis of various organ systems, glycogen is depleted and is absent in the cercomer of mature Archigetes. The exact nature of the secretory products of the cercomer tegument remains unclear; perhaps some have a protective function (Smyth 1969, Lumsden 1975). Additional ideas concerning the functional significance of the cercomer can be found in Jarecka et al. (1981) and Mackiewicz (1984). Once the procercoid is in the vertebrate host, the cercomer is shed.

In the final analysis, there is only one characteristic that basically distinguishes a progenetic procercoid from a normal one: maturity of the reproductive system. In $A$. sieboldi from oligochaetes, the reproductive system is fully functional: uterine glands are present and oogenesis, spermiogenesis and vitellogenesis produce viable eggs. In non-progenetic species, procercoids lack uterine glands and the reproductive system is just in the early stages of organogenesis (Table 1). The net effect of this difference is to secondarily reduce the life cycle from two to one host. Though viable eggs are produced, they cannot be disseminated because the gonopore is non-functional. Whatever stimulus initiates and controls reproductive maturation in $A$. sieboldi, it has to be "turned on" to initiate the progenetic development.

As summarised in Table 1, the progenetic state of $A$. sieboldi can be characterised by the following primary, larval features: the presence of a cercomer; surface filamentous coat (glycocalyx) covering the whole surface of the worm; the presence of only penetration glands; procercoid-type (i.e. wide) connection of circular and longitudinal external tegumental muscles; the absence of a dense zone of the basal lamina beneath the epithelial cytoplasm of all reproductive organs and ducts; a procercoid-type orthogonal plan of the nervous system; and a non-functional gonopore. Primary adult characteristics are: functional oogenesis, spermiogenesis and vitellogenesis; the presence of uterine glands; a welldeveloped longitudinal tegumental muscle layer between tegumental cytons; and different microtriches, characteristic of caryophyllidean stages from the intestine of fish. In effect, progenetic $A$. siebold $i$ is a mosaic of larval and adult characters that is manifested at the ultrastructural, morphological, and developmental levels.

From an evolutionary perspective, progenesis results in an abbreviated life cycle that increases reproductive potential for the species and can serve, as in the present case of $A$. sieboldi, to perpetuate a parasite in those instances where the definitive host is absent. Progenesis, therefore, appears to be a good hedge against extinction. Indeed, progenesis may also be a process that played a major role in the early evolution of the Caryophyllidea itself, by first appearing in the plerocercoid stage of a cycle with a strobilate ancestor from fish.

Acknowledgements. A part of this paper was presented at the IV International Workshop on Cestode Systematics, University of Connecticut, Storrs, USA in July 2002. We wish to express our sincere appreciation to Prof. Janine N. Caira for her financial support. Travel funds for Larisa Poddubnaya to attend the Workshop were provided from NSF PEET grant no. DEB-0118882 to Janine N. Caira and T.R. Ruhnke.

\section{REFERENCES}

BARON P. 1968: On the histology and ultrastructure of Cysticercus longicollis, the cysticercus of Taenia crassiceps Zeder, 1800 (Cestoda: Cyclophyllidea). Parasitology 58: 497-513.

BAZITOV A.A. 1981: [Caryophyllidea, their origin and position in the phylum of Platyhelminthes.] Zh. Obshch. Biol. 42: 920-927. (In Russian.)

BEGUIN F. 1966: Étude en microscope électronique de la cuticle et ses structures associés chez quelques cestodes. Essai d'histologie comparée. Z. Zellforsch. 72: 30-46.

CALENTINE R.L. 1964: The life cycle of Archigetes iowensis (Cestoda: Caryophyllaeidae). J. Parasitol. 50: 454-458.

CALENTINE R.L., CHRISTENSEN B.M., CHRISTENSEN L.A. 1970: Specificity of caryophyllaeid cestodes for their intermediate hosts. J. Parasitol. 56: 346-349.

CALENTINE R.L., DeLONG B.L. 1966: Archigetes sieboldi (Cestoda: Caryophyllaeidae) in North America. J. Parasitol. 52: 428-431.
CAMERON T.W.M. 1956: Parasites and Parasitism. John Wiley and Sons, New York, $322 \mathrm{pp}$.

CHERVY L. 2002: The terminology of larval cestodes or metacestodes. Syst. Parasitol. 52: 1-33.

CONN D.B. 1988: The role of cellular parenchyma and extracellular matrix in the histogenesis of the paruterine organ of Mesocestoides lineatus (Platyhelminthes: Cestoda). J. Morphol. 197: 303-314.

CONN D.B., ETGES F.J., SIDNER R.A. 1984: Fine structure of the gravid paruterine organ and embryonic envelopes of Mesocestoides lineatus (Cestoda). J. Parasitol. 70: 68-77.

DAVYDOV V.G., MIKRYAKOV V.R. 1988: [Adaptive structures of body coverings of some cestodes associated with protection of parasites from action of the host organism.] In: Immunologicheskie i biokhimicheskie aspekty vzaimootnoshenii gelmintov i khozyaev. Nauka, Moskva, pp. 88-100. (In Russian.) 
DAVYDOV V.G., PODDUBNAYA L.G. 1988: [Functional morphology of frontal and uterine glands in cestodes of the order Caryophyllidea.] Parazitologiya 22: 449-457. (In Russian.)

DAVYDOV V.G., PODDUBNAYA L.G., KOLESNIKOVA G.A. 1994: [Ultrastructure of genital system ducts of Caryophyllaeus laticeps (Cestoda, Caryophyllidea).] Parazitologiya 28: 501-509. (In Russian.)

DAVYDOV V.G., PODDUBNAYA L.G., KUPERMAN B.I. 1997: [An ultrastructure of some systems of the Diplocotyle olrikii (Cestoda: Cyathocephalata) in relation to peculiarities of its life cycle.] Parazitologiya 31: 132-141. (In Russian.)

DUBININA M.N. 1966: [Ligulidae of Russian Fauna.] Nauka Publ. House, Moscow - Leningrad, 261 pp. (In Russian.)

DUBININA M.N. 1980: [Importance of attachment organs for phylogeny of tapeworms.] Parazitol. Sb. 29: 65-83. (In Russian.).

EHLERS U. 1985: Phylogenetic relationships within the Platyhelminthes. In: S. Conway Morris, J.D. George, R. Gibson and H.M. Platt (Eds.), The Origins and Relationships of Lower Invertebrates. Oxford University, Oxford, pp. 143-158.

FREEMAN R. 1973: Ontogeny of cestodes and its bearing on their phylogeny and systematics. Adv. Parasitol. 11: 481557.

FUHRMANN O. 1931: Dritte Klasse des Cladus Plathelminthes: Cestoidea. In W. Kükenthal and T. Krumbach (Eds.), Handbuch der Zoologie. Vol. II/1. Walter de Gruyter, Berlin, pp. 141-416.

FURTADO J.I. 1963: A new caryophyllaeid cestode, Lytocestus parvulus, from a Malayan catfish. Ann. Mag. Nat. Hist. 6: 97-106.

GOGGINS I. 1980: Apical end organ structure and histochemistry in plerocercoids of Proteocephalus ambloplitis. Int. J. Parasitol. 10: 97-101.

GOMORI G. 1952: Microscopic Histochemistry. University of Chicago Press, Chicago, 273 pp.

GRAEBER K., STORCH V. 1979: Elektronenmikroskopische and morphometrische Untersuchungen am Integument von Cestoda and Trematoda (Plathelminthes). Zool. Anz. 202: 331-347.

HANNA R.E.B. 1980a: Fasciola hepatica: glycocalyx replacement in the juvenile as a possible mechanism for protection against host immunity. Exp. Parasitol. 50: 103114.

HANNA R.E.B. 1980b: Fasciola hepatica: autoradiography of protein synthesis, transport, and secretion by the tegument. Exp. Parasitol. 50: 297-304.

HAYUNGA E.G. 1979: The structure and function of the scolex glands of three caryophyllid tapeworms. Proc. Helminthol. Soc. Wash. 46: 171-179.

HOBERG E.P., GARDNER S.L., CAMPBELL R.A. 1999: Systematics of the Eucestoda: advances toward a new phylogenetic paradigm, and observations on the early diversification of tapeworms and vertebrates. Syst. Parasitol. 42: 1-12.

HOBERG E.P., MARIAUX J., BROOKS D.R. 2001: Phylogeny among orders of the Eucestoda (Cercomeromorphae): integrating morphology, molecules and total evidence. In: D.T.J. Littlewood and R.A. Bray (Eds.), Interrelationships of the Platyhelminthes. Taylor \& Francis, London, pp. 112-126.

HOBERG E.P., MARIAUX J., JUSTINE J.-L., BROOKS D.R., WEEKES P.J. 1997: Phylogeny of the orders of the Eucestoda (Cercomeromorphae) based on comparative morphology: historical perspectives and a new working hypothesis. J. Parasitol. 83: 1128-1147.

JARECKA L., MICHAJLOW W., BURT M.D.B. 1981: Comparative ultrastructure of cestode larvae and Janicki's cercomer theory. Acta Parasitol. Pol. 28: 65-72.

JOYEUX C.H., BAER J.G. 1961: Classe des Cestodes. In: P.-P. Grassé (Ed.), Traité de Zoologie. Tome 4, Fasc. 1. Masson, Paris, pp. 345-560.

KENNEDY C.R. 1965: Taxonomic studies on Archigetes Leuckart, 1878 (Cestoda, Caryophyllidea). Parasitology 55: 439-451.

KIRSCHENBLAT J.D. 1941: [Host-specificity of parasites.] Uspechi sovremennoi biologii 14: 271-294. (In Russian.)

KODEDOVÁ I., DOLEŽEL D., BROUČKOVÁ M., JIRKU゚ M., HYPŠA V., LUKEŠ J., SCHOLZ T. 2000: On the phylogenetic positions of the Caryophyllidea, Pseudophyllidea and Proteocephalidea (Eucestoda) inferred from 18S rRNA. Int. J. Parasitol. 30: 1109-1113.

KOTIKOVA E.A. 1967: [Histochemical method of studying the morphology of the nervous system in Platyhelminthes.] Parazitologiya 1: 79-81. (In Russian.)

KOTIKOVA E.A. 1976: [Evolution of cestode nervous systems and alteration patterns of trunks number.] In: The significance of processes of polymerization and oligomerization in evolution. Zoological Institute of Academy of Sciences of the USSR, Leningrad, pp. 39-41.

KOTIKOVA E.A., KUPERMAN B.I. 1977: [The development of the nervous apparatus of Triaenophorus nodulosus (Cestoidea, Pseudophyllidea) during ontogenesis.] Parazitologiya 11: 252-259. (In Russian.)

KOTIKOVA E.A., KUPERMAN B.I. 1978: [The anatomy of the nervous apparatus in cestodes of the families Amphicotylidae and Diphyllobothriidae (Pseudophyllidea).] Parazitologiya 12: 210-217. (In Russian.)

KULAKOVSKAYA O.P., DEMSHIN N.I. 1978: [The origin and the phylogenetic relationships of the Caryophyllidea.] Problemy gidroparazitologii, Naukova Dumka, Kiev, pp. 95-104. (In Russian.)

KUPERMAN B.I. 1988: Functional Morphology of Lower Cestodes. Ontogenetic and Evolutionary Aspects. Nauka, Leningrad, $188 \mathrm{pp}$.

KUPERMAN B.I., DAVYDOV V.G. 1981: The fine structure of glands in oncospheres, procercoids and plerocercoids of Pseudophyllidea (Cestoidea). Int. J. Parasitol. 12: 135144.

LETHBRIDGE R.C., GIJSBERRS M.F. 1974: Penetration gland secretion by hexacanths of Hymenolepis diminuta. Parasitology 68: 303-311.

LITTLEWOOD T.J., CRIBB T.H., OLSON P.D., BRAY R.A. 2001: Platyhelminth phylogenetics - a key to understanding parasitism? Belg. J. Zool. 131: 35-46.

LLEWELLYN J. 1965: The evolution of parasitic platyhelminths. In: A.E.R. Taylor (Ed.), Evolution of Parasites. Third Symposium of the British Society of Parasito- 
logy. Blackwell Scientific Publications, Oxford, pp. 4778.

LUMSDEN R.D. 1975: Surface and cytochemistry of parasitic helminths. Exp. Parasitol. 37: 267-339.

LUMSDEN R.D., OAKS J.A., MUELLER J.F. 1974: Brush border development in the tegument of the tapeworm, Spirometra mansoides. J. Parasitol. 60: 209-226.

LUPPA H. 1977: Grundlagen der Histochemie. AkademieVerlag, Berlin, 343 pp.

LYNGDOH R.D., TANDON V. 1992: Organization of nervous system in Lytocestus indicus (Cestoda: Caryophyllidea). Zool. Anz. 228: 238-247.

LYNGDOH R.D., TANDON V. 1994: Nervous system in the monozoic cestode, Djombangia penetrans (Caryophyllidea) as revealed by nonspecific esterases and cholinesterase activity. Acta Parasitol. 39: 82-87.

MACKIEWICZ J.S. 1972: Caryophyllidea (Cestoidea): a review. Exp. Parasitol. 31: 417-512.

MACKIEWICZ J.S. 1981: Caryophyllidea (Cestoidea): evolution and classification. Adv. Parasitol. 19: 139-206.

MACKIEWICZ J.S. 1982: Caryophyllidea (Cestoidea): perspectives. Parasitology 84: 397-417.

MACKIEWICZ J.S. 1984: Cercomer theory: significance of sperm morphology, oncosphere metamorphosis, polarity reversal, and the cercomer to evolutionary relationships of Monogenea to Cestoidea. Acta Parasitol. Pol. 29: 11-21.

MALMBERG G. 1986: The major parasitic platyhelminth classes - progressive or regressive evolution? Hydrobiologia 132: 23-29.

MAMAEV Yu.L. 1975: [On hypotheses of the origin of cestodes from "Archigetes-like ancestors", parasites of Oligochaeta.] Zool. Zh. 54: 1277-1283. (In Russian.)

MARIAUX J. 1998: A molecular phylogeny of the Eucestoda. J. Parasitol. 84: 114-124.

MARIAUX J., OLSON P.D. 2001: Cestode systematics in the molecular era. In: D.T.J. Littlewood and R.A. Bray (Eds.), Interrelationships of the Platyhelminthes. Taylor \& Francis, London, pp. 127-134.

MOCZOŃ T. 1996: A serine proteinase in the penetration glands of the hexacanths of Hymenolepis diminuta (Cestoda, Cyclophyllidea). Parasitol. Res. 82: 67-71.

MRÁZEK A. 1898: Archigetes appendiculatus Ratz. In: Věstník Král. České Společnosti Nauk, Třída mathematicko-př́rodovědecká, Prague, 32, 47 pp.

NYBELIN O. 1922: Anatomisch-systematische Studien über Pseudophyllideen. Göteborgs Kungl. Vetenkaps-och. Viterhets-Samhalles Handlingar, Fjärde Följden, 26, 228 pp.

NYBELIN O. 1962: Zur Archigetes-Frage. Zool. Bidr. Upps. 35: 292-306.

OAKS J.A., HOLY J.M. 1994: Hymenolepis diminuta: two morphologically distinct tegumental secretory mechanisms are present in the cestode. Exp. Parasitol. 79: 292-300.

OAKS J.A., LUMSDEN R. 1971: Cytological studies on the absorptive surfaces of cestodes. V. Incorporation of carbohydrate-containing macromolecules into tegument membranes. J. Parasitol. 57: 1256-1258.

OLSON P.D., LITTLEWOOD D.T.J., BRAY R.A., MARIAUX J. 2001: Interrelationships and evolution of the tapeworms (Platyhelminthes: Cestoda). Mol. Phylog. Evol. 19: 443-467.

PAPPAS P.W., UGLEM G.L. 1990: Hymenolepis diminuta (Cestoda) liberates an inhibitor of proteolytic enzymes during in vitro incubation. Parasitology 101: 455-464.

PEARSE A.G.E. 1960: Histochemistry. Theoretical and Applied. Second Edition. J. and A. Churchill, London, 962 pp.

PODDUBNAYA L.G. 1995: [Peculiarities of the integument genesis in procercoids of caryophyllidean cestodes.] Parazitologiya 29: 13-18. (In Russian.).

PODDUBNAYA L.G. 1996: [The development of microtriches in caryophyllid cestodes.] Parazitologiya 30: 126131. (In Russian.)

PODDUBNAYA L.G. 2002: [Phylogeny and origin of the Caryophyllidea related to their ultrastructural organization.] Uspechi Sovremennoi Biologii 122: 239-248. (In Russian.)

PODDUBNAYA L.G., DAVYDOV V.G., KUPERMAN B.I. 1984: [A morpho-functional study of Archigetes sieboldi Leuckart (1878) (Cestoda: Caryophyllidea) concerning the peculiarities of its life cycle.] Dokl. AN SSSR 276: 10101013. (In Russian.)

PODDUBNAYA L.G., DAVYDOV V.G., KUPERMAN B.I. 1986: [Morpho-functional study of some species of cestodes of order Caryophyllidea (Cestoda).] Biology of Inland Waters Information Bulletin 53 (56): 208-217. (In Russian.)

RAHEMO Z.I.F., AL-KALAK S.N. 1995: The nervous system of two caryophyllid cestodes with special reference to the neurosecretory system. Riv. Parassitol. 12 (44): 35-45.

RICHARDS S.K., ARME C. 1981: Observations on the microtriches and stages in their development and emergence in Caryophyllaeus laticeps (Caryophyllidea: Cestoda). Int. J. Parasitol. 11: 369-375.

RICHARDS S.K., ARME C. 1982: The microarchitecture of the structured bodies in the tegument of Caryophyllaeus laticeps. J. Parasitol. 68: 425-432.

SMYTH J.D. 1969: The Physiology of Cestodes. W.H. Freeman and Company, San Francisco, 279 pp.

STUNKARD H.W. 1975: Life-histories and systematics of parasitic flatworms. Syst. Zool. 24: 378-385.

SWIDERSKI Z., MACKIEWICZ J.S. 1976: Electron microscope study of vitellogenesis in Glaridacris catostomi (Cestoidea: Caryophyllidea). Int. J. Parasitol. 6: 61-73.

SWIDERSKI Z., TKACH V. 1997: Differentiation and ultrastructure of the paruterine organs and paruterine capsules, in the nematotaeniid cestode Nematotaenia dispar (Goeze, 1782) Lühe, 1910, a parasite of amphibians. Int. J. Parasitol. 27: 635-644.

THREADGOLD L.T. 1976: Fasciola hepatica: ultrastructure and histochemistry of the glycocalyx of the tegument. Exp. Parasitol. 39: 119-134.

THREADGOLD L.T., HOPKINS C.A. 1981: Schistocephalus solidus and Ligula intestinalis: pinocytosis by the tegument. Exp. Parasitol. 51: 444-456.

TIMOSHECHKINA L.G. 1984: [Aspects of the ultrastructure of the tegument and glandular apparatus of Caryophyllaeus laticeps.] Biologiya Vnutrennich Vod, Informatsionnyi Byulleten 62: 30-33. (In Russian.) 
YAMANE Y., NAKAGAWA A., MAKINO Y., HIRAI K. 1982: An electron microscopic study of subtegumental cells and associated structures of Spirometra erinacei. Jpn. J. Parasitol. 31: 487-497.

WARDLE R.A., McLEOD J.A. 1952: The Zoology of Tapeworms. The University of Minnesota Press, Minneapolis, $780 \mathrm{pp}$.

WHITTINGTON I.D., CRIBB B.W. 2001: Adhesive secretions in the Platyhelminthes. Adv. Parasitol. 48: 101-223.

Received 17 January 2003
WILL H. 1883: Anatomie von Caryophyllaeus mutabilis Rud. Ein Beitrag zur Kenntnis der Cestoden. Z. Wiss. Zool. 56: $1-39$.

WIŚNIEWSKI L.W. 1930: Das Genus Archigetes. Eine Studie zur Anatomie, Histogenese, Systematik und Biologie. Mem. Acad. Pol. Sci. Lett., Sci. Math. Nat., Ser. B, Sci. Nat., 2, pp. 1-160.

Accepted 10 September 2003 